\title{
EFEKTIVITAS MODEL PEMBELAJARAN INKUIRI TERBIMBING PADA BIOLOGI UMUM TERHADAP KEMAMPUAN BERPIKIR MAHASISWA
}

\author{
Hefi Rusnita Dewi \\ STKIP PGRI Bangkalan \\ rusnitadewi69@gmail.com
}

\begin{abstract}
Abstrak
Tujuan penelitian adalah untuk mendeskripsikan keefektifan model pembelajaran inkuiri terbimbing terhadap kemampuan berpikir mahasiswa pada biologi.umum. Inkuiri terbimbing (guided inquiry) merupakan model pembelajaran yang membantu mahasiswa untuk belajar, memperoleh pengetahuan dengan cara menemukan sendiri.. Pendidik lebih banyak menggunakan metode ceramah dengan alasan lebih menghemat waktu dan semua materi dapat diberikan. Tatap muka untuk kegiatan praktikum juga sangat minim biasanya dilakukan hanya 1 kali dalam satu semester. Selebihnya pembelajaran dilakukan dengan ceramah, padahal banyak materi dalam biologi yang membutuhkan kegiatan eksperimen dan pengamatan. Metode seperti ini kurang memberikan kesempatan kepada mahasiswa untuk meningkatkan kemampuan berpikirnya. Kecakapan akademik mahasiswa tidak akan berkembang dalam diri mahasiswa ketika proses pembelajarannya tidak mengakomodasi terjadinya kegiatan ilmiah melalui kegiatan eksperimen sehingga dapat mengembangkan kemampuan berpikirnya.Harapan peneliti, bahwa dengan model pembelajaran inkuiri terbimbing merupakan salah satu cara efektif untuk membantu mahasiswa meningkatkan kemampuan berpikir. Desain ujicoba menggunakan rancangan pre-test and posttest group. Pre test untuk mengetahui keadaan awal subyek sebelum diberi perlakuan dan post tes dilakukan di akhir pertemuan. Hasil penelitian menunjukkan adanya peningkatan kemampuan berpikir mahasiswa setelah penerapan model pembelajaran inkuiri terbimbing pada Biologi umum, dengan perolehan hasil posttest kemampuan berpikir level relasional dari $0 \%$ meningkat menjadi 47\% dan level Abstrak diperluas dari $0 \%$ meningkat menjadi $33 \%$. Kesimpulan dari penelitian ini, bahwa Model pembelajaran Inkuiri terbimbing pada Biologi Umum efektif terhadap peningkatan kemampuan berpikir mahasiswa..
\end{abstract}

Kata Kunci: Efektivitas, Inkuiri Terbimbing, Biologi Umum, Kemampuan Berpikir.

\begin{abstract}
The purpose of this study is to describe the effectiveness of guided inquiry learning models for students' thinking abilities in biology. Guided inquiry (guided inquiry) is a learning model that helps students to learn, gain knowledge by discovering themselves. Educators use the lecture method more on the grounds that they save time and all material can be provided. Face to face for practicum activities is also very minimal usually done only once a semester. The rest of the learning is done with lectures, even though a lot of material in biology requires experimentation and observation. Methods like this do not provide opportunities for students to improve their thinking abilities. Student academic skills will not develop in students when the learning process does not accommodate the occurrence of scientific activities through experimental activities so that they can develop their thinking skills. Researchers hope that the guided inquiry learning model is an effective way to help students improve their thinking skills. The trial design uses a pre-test and post-test group design. Pre test to find out the initial state of the subject before being given treatment and post test conducted at the end of the meeting. The results showed an increase in students' thinking skills after the application of the guided inquiry learning model in general Biology, with posttest results in the ability to think of relational levels from $0 \%$ to $47 \%$ and Abstract levels expanded from $0 \%$ to 33\%. The conclusion of this study, that the Guided Inquiry learning model in General Biology is effective against improving students' thinking skills.
\end{abstract}

Keywords: Effectiveness, Guided Inquiry, General Biology, Thinking Ability

\section{PENDAHULUAN}

Inkuiri terbimbing (guided inquiry) adalah model pembelajaran yang membantu mahasiswa untuk belajar, mendapatkan pengetahuan dengan cara menemukan sendiri. Di dalam model ini juga tercakup penemuan makna, organisasi, dan struktur 
dari ide atau gagasan. Sehingga secara bertahap peserta didik dapat belajar bagaimana cara mengorganisasikan serta melakukan penelitian guna mencapai tujuan pembelajaran (Wahyudi, 2013).

Menurut Permana (2015) memaparkan hasil temuannya yaitu melalui hasil tanya jawab antara pendidik dalam menerapkan pembelajarannya biologi lebih terfokus pada teacher centered. Pendidik lebih banyak menggunakan metode ceramah dengan alasan lebih menghemat waktu dan semua materi dapat diberikan. Tatap muka untuk kegiatan praktikum juga sangat minim biasanya dilakukan hanya 1 kali dalam satu semester. Selebihnya pembelajaran dilakukan dengan ceramah, padahal banyak materi dalam biologi yang membutuhkan kegiatan eksperimen dan pengamatan. Metode seperti ini kurang memberikan kesempatan kepada mahasiswa untuk meningkatkan kemampuan berpikirnya. Kecakapan akademik mahasiswa tidak akan berkembang dalam diri mahasiswa ketika proses pembelajarannya tidak mengakomodasi terjadinya kegiatan ilmiah melalui kegiatan eksperimen sehingga dapat mengembangkan kemampuan berpikirnya.

Berdasarkan fakta di atas perlu adanya perangkat pembelajaran yang sesuai untuk dibuat oleh dosen dalam menerapkan model pembelajaran yang melibatkan mahasiswa dalam kegiatan pembelajaran secara langsung sekaligus melatih kecakapan akademik dan kecakapan sosial mahasiswa yaitu dengan model pembelajaran inkuiri terbimbing akan merangsang mahasiswa untuk menumbuhkan kreativitanya. Harapan peneliti, bahwa dengan model pembelajaran inkuiri terbimbing merupakan salah satu cara efektif untuk membantu mahasiswa meningkatkan kemampuan berpikir. Berdasarkan latar belakang di atas, maka rumusan masalah dalam penelitian ini adalah "Bagaimanakah efektivitas model pembelajaran inkuiri terbimbing pada biologi umum terhadap kemampuan berpikir mahasiswa ?".

\section{METODE}

Desain dalam penelitian ini menggunakan pre-eksperimen dengan pola dasar "One Group Pretest and Postest Design",

\section{$\mathrm{O} 1 \mathrm{X}^{\mathrm{O}} 2$}

(Arikunto, 2006)

Keterangan:

$\mathrm{O}_{1}$ : Pre-test dilakukan sebelum pembelajaran Inkuiri Terbimbing pada Biologi Umum.

$\mathrm{X}$ : Perlakuan (treatment) dengan pembelajaran Inkuiri Terbimbing pada Biologi Umum

$\mathrm{O}_{1}$ : Post-test dilakukan sesudah perlakuan (treatment) dengan pembelajaran Inkuiri Terbimbing pada Biologi Umum

Penelitian ini dilakukan terhadap 15 orang mahasiswa STKIP PGRI Bangkalan angkatan 2018-2019. Teknik pengumpulan data yang digunakan dalam penelitian ini adalah: (1) pengamatan (observasi); (2) tes; dan (3) angket.

Instrumen yang digunakan untuk mengumpulkan data dalam penelitian ini: (1) Lembar Pengamatan Keterlaksanaan RPP. Lembar ini digunakan untuk dasar menilai keterlaksanaan semua langkah langkah pembelajaran yang terdapat dalam peranngkat pembelajaran, sehingga dapat diperoleh data tentang keterlaksanaan RPP pada saat proses belajar mengajar. (2) Lembar Pengamatan Aktivitas Mahasiswa. Lembar ini digunakan pengamat untuk mengamati aktivitas mahasiswa selama proses kegiatan pembelajaran berlangsung. (3) Lembar Angket Respon Mahasiswa. Angket digunakan untuk mengetahui respon mahasiswa terhadap media pembelajaran setelah proses pembelajaran Inkuiri Terbimbing pada Biologi Umum berlangsung. Angket ini diisi secara individual dan bersifat tertutup, dipilih secara obyektif dan jujur. (4) Soal Tes Kemampuan Berpikir. Instrumen ini berupa soal uraian diberikan pada saat pretes dan posttes, yang digunakan untuk memperoleh data mengenai kemampuan berpikir mahasiswa.

Teknik analisis data keterlaksanaan RPP menggunakan deskriptif kualitatif. Nilai dari keterlaksanaan pembelajaran yang diperoleh dihitung dengan menggunakan persamaan sebagai berikut: 
$P=$ jumlah tahap pembelajaran yg dilaksanakan jumlah seluruh tahap pembelajaran

Pelaksanaan pengamatan masing-masing pengamat memberikan penilaian (4: baik, 3: cukup baik, 2: kurang baik, dan 1: tidak baik). Kriteria penilaian yang diperoleh dengan membandingkan rata-rata skala penilaian diberikan kedua pengamat dengan kriteria penilaian di bawah ini:
$1.00-1.49$ : Tidak baik
$1.50-2.49$ : Kurang baik
2.50-3.49 : Cukup baik
$3.50-4.00 \quad$ : Baik

(Ratumanan \& Laurens, 2006)

Teknik analisis data analisis pengamatan aktivitas mahasiswa dalam dengan menggunakan data pengamatan selama kegiatan belajar pada saat proses pembelajaran berlangsung

Untuk menghitung persentase aktivitas belajar mahasiswa digunakan rumus:

\section{Frek.Ak.dilakukan X Jml.wkt tiap peng $x$ 100\%} Juml.mhs yg diamati X Tot Waktu Pengmtan

Teknik analisis data respon mahasiswa dianalisis secara deskriktif kuantitatif dengan presentase yaitu jumlah mahasiswa yang memberikan respon ya atau tidak dibagi dengan jumlah keseluruhan mahasiswa yang mengisi angket dikalikan $100 \%$. Analisis data angket respon mahasiswa menggunakan skala Guttman. Mahasiswa menjawab Ya bernilai (1) dan siswa menjawab Tidak bernilai (0). Secara matematis dapat ditulis sebagai berikut:

Keterangan:

$$
P=\frac{\sum K}{\sum N} \times 100 \%
$$

$P$ : Persentase skor respon mahasiswa

$\sum K$ : Jumlah mahasiswa yang memilih jawaban Ya atau Tidak

$\sum N$ : Jumlah mahasiswa yang mengisi angket

Persentase respon mahasiswa dikonversi dengan kriteria sebagai berikut:
Angka 0\% - 20\%
$=$ Sangat lemah
Angka 21\% - 40\%
$=$ Lemah
Angka 41\% - 60\%
= Cukup
Angka $61 \%-80 \%=$ Kuat
Angka $81 \%-100 \%=$ Sangat kuat

(Riduwan, 2010)
Analisis Tes Kemampuan Berpikir dilakukan dengan tes diawal dan di akhir proses pembelajaran menggunakan lembar penilaian dalam bentuk tes tulis yang bersumber dari instrumen penilaian tes kemampuan berpikir mahasiswa yang merupakan tes yang digunakan untuk mengukur tingkat kemampuan berpikir mahasiswa berupa jawaban terhadap pertanyaan materi ajar yang diperoleh mahasiswa, yang berupa soal tes uraian.

Tabel 1. Pedoman Kategori Kemampuan Berpikir

\begin{tabular}{|c|c|}
\hline Level & Kategori \\
\hline 1 & Prastruktural \\
\hline 2 & Unistruktural \\
\hline 3 & Multistruktural \\
\hline 4 & Relasional \\
\hline 5 & Abstrak diperluas \\
\hline
\end{tabular}

\section{HASIL DAN PEMBAHASAN}

\section{Hasil Analisis Keterlaksanaan RPP}

Penilaian dari dua orang pengamat terhadap pelaksanaan langkah-langkah proses pembelajaran sesuai dengan RPP memberikan nilai rata-rata 3,8 sehingga termasuk pada kriteria Baik.

\section{Hasil Analisis aktivitas mahasiswa}

Analisis pengamatan aktivitas mahasiswa dalam dengan menggunakan data pengamatan selama kegiatan belajar pada saat menerapkan pembelajaran.

Rata - rata persentase aktivitas mahasiswa $75 \%$. Jumlah ini sudah memenuhi kriteria waktu ideal.

\section{Analisis Respon Mahasiswa}

Respon mahasiswa dianalisis secara deskriktif kuantitatif dengan presentase yaitu jumlah mahasiswa yang memberikan respon dengan nilai $83 \%$, sehingga termasuk kriteria sangat kuat.

\section{Analisis Tes Kemampuan Berpikir}

Tes dilakukan diawal dan di akhir proses pembelajaran menggunakan lembar penilaian dalam bentuk tes tulis yang bersumber dari instrumen penilaian tes kemampuan berpikir mahasiswa yang merupakan tes yang digunakan untuk mengukur tingkat kemampuan berpikir mahasiswa dengan menilai kualitas respon 
atau jawaban yang diberikan mahasiswa dengan acuan taksonomi SOLO yang terdiri dari lima tingkatan, yaitu prastuktural, unistructural, multistruktural, relasional, dan abstrak diperluas.

Tabel 2. Hasil Tes Kemampuan Berpikir Mahasiswa

\begin{tabular}{|l|c|c|}
\hline Level SOLO & Pretest & Posttest \\
\hline Prastruktural & $34 \%$ & $0 \%$ \\
\hline Unistruktural & $53 \%$ & $7 \%$ \\
\hline Multistrktural & $13 \%$ & $13 \%$ \\
\hline Relasional & $0 \%$ & $47 \%$ \\
\hline $\begin{array}{l}\text { Abstrak } \\
\text { Diperluas }\end{array}$ & $0 \%$ & $33 \%$ \\
\hline
\end{tabular}

\section{DAFTAR PUSTAKA}

Jacobsen, D.A., Eggen, P., dan Kauchak, P. (2009). Methods for Teaching (Metode-metode Pengajaran Meningkatkan Belajar Siswa TK-SMA) Edisi ke-8. Yogyakarta. Pustaka Pelajar.

Joyce \& Weil. (2009). Models of Teaching (Model-model Pengajaran). Pustaka Pelajar. Yogyakarta.

Kardi,S. (2013). Model Pembelajaran Langsung Inkuiri Sains Teknologi dan Masyarakat. Surabaya: Universitas Negeri Surabaya.

Permana, D. (2015). Pengembangan Perangkat Pembelajaran Biologi Model Inquiry Berorientasi Life Skill di Madrasah Aliyah. Universitas Negeri Surabaya.
Adanya peningkatan kemampuan berpikir mahasiswa setelah penerapan model pembelajaran inkuiri terbimbing pada Biologi umum, yang ditunjukkan pada tabel 2, dengan perolehan hasil posttest kemampuan berpikir level relasional dari $0 \%$ meningkat menjadi 47\% dan level Abstrak diperluas dari 0\% meningkat menjadi $33 \%$.

\section{SIMPULAN}

Model pembelajaran Inkuiri terbimbing pada Biologi Umum efektif terhadap peningkatan kemampuan berpikir mahasiswa.

Sanjaya, W. (2011). Strategi Pembelajaran Berorientasi Standar Proses Pendidikan. Jakarta : Kencana Prenada Media Group.

Sudrajad, A. (2011). Pembelajaran Inkuiri. http:// akhmadsudrajad. Wordpress.com/ diakses 08 juni 2012.

Wahyudi, L.E. \& Z.A. Imam Supardi. (2013). "Penerapan Model Pembelajaran Inkuiri Terbimbing Pada Pokok Bahasan Kalor Untuk Melatihkan Keterampilan Proses Sains Terhadap Hasil Belajar Di SMAN 1 Sumenap". Journal Inovasi Pendidikan Fisika. Vol.02 No.02, 6265.

Zuriyani, E. (2011). Strategi Pembelajaran Inkuiri Pada mata pelajaran IPA. Palembang: Widiyaiswara BDK 